\title{
SOIL WATER EROSION UNDER DIFFERENT CULTIVATION SYSTEMS AND DIFFERENT FERTILIZATION RATES AND FORMS OVER 10 YEARS $^{(1)}$
}

\author{
Ildegardis Bertol $^{(2)}$, Fabrício Tondello Barbosa ${ }^{(2)}$, Álvaro Luiz Mafra ${ }^{(2)}$ \& Murilo Córdova \\ Flores $^{(3)}$
}

\begin{abstract}
SUMMARY
The action of rain and surface runoff together are the active agents of water erosion, and further influences are the soil type, terrain, soil cover, soil management, and conservation practices. Soil water erosion is low in the no-tillage management system, being influenced by the amount and form of lime and fertilizer application to the soil, among other factors. The aim was to evaluate the effect of the form of liming, the quantity and management of fertilizer application on the soil and water losses by erosion under natural rainfall. The study was carried out between 2003 and 2013 on a Humic Dystrupept soil, with the following treatments: T1 - cultivation with liming and corrective fertilizer incorporated into the soil in the first year, and with $100 \%$ annual maintenance fertilization of $P$ and $K$; T2 - surface liming and corrective fertilization distributed over five years, and with $75 \%$ annual maintenance fertilization of $P$ and $K$; $T 3$ - surface liming and corrective fertilization distributed over three years, and with $50 \%$ annual maintenance fertilization of $P$ and K; T4 - surface liming and corrective fertilization distributed over two years, and with $25 \%$ annual maintenance fertilization of $P$ and $K$; $T 5$ - fallow soil, without liming or fertilization. In the rotation the crops black oat (Avena strigosa), soybean (Glycine max), common vetch (Vicia sativa), maize (Zea mays), fodder radish (Raphanus sativus), and black beans (Phaseolus vulgaris). The split application of lime and mineral fertilizer to the soil surface in a no-tillage system over three and five years, results in better control of soil losses than when split in two years. The increase in the amount of fertilizer applied to the soil surface under no-tillage cultivation increases phytomass production and reduces soil loss by water erosion. Water losses in treatments under no-tillage cultivation were low in all crop cycles, with a similar behavior as soil losses.
\end{abstract}

Index terms: crop mass, water loss, soil loss, natural rainfall.

(1) Received for publication on March 27, 2014 and approved on August 22, 2014

(2) Professor, Department of Soils and Natural Resources, Universidade do Estado de Santa Catarina - UDESC. Av. Luiz de Camões, 2090, Bairro Conta Dinheiro. CEP 88520-000 Lages (SC), Brazil. Fellow PQ of CNPq. E-mail: ildegardis.bertol@udesc.br, fabricio.barbosa@udesc.br, alvaro.mafra@udesc.br

(3) Scientific Initiation Scholarship grantee, Department of Soils and Natural Resources, UDESC. E-mail: murilocflores@gmail.com 


\title{
RESUMO: EROSÃO HÍDRICA EM SOLO SUBMETIDO A DIFERENTES SISTEMAS DE CULTIVO, DOSES E FORMAS DE ADUBAÇÃO, DURANTE 10 ANOS
}

\begin{abstract}
A chuva e o escoamento superficial, associados, são os agentes ativos na erosão hidrica, a qual é influenciada ainda pelo tipo de solo, relevo, cobertura e manejo do solo e práticas conservacionistas. A semeadura direta é um sistema de manejo que apresenta baixa erosão hídrica, sendo influenciada pela quantidade e forma de aplicação de corretivos e adubos no solo, entre outros fatores. O objetivo deste trabalho foi avaliar o efeito da forma de aplicação de calcário, da quantidade e do manejo de aplicação de adubos sobre as perdas de solo e água por erosão hídrica, sob chuva natural. Este trabalho foi conduzido entre 2003 e 2013 em um Cambissolo Húmico, com os seguintes tratamentos: T1 - cultivo com calagem e adubação corretiva incorporada ao solo no $1^{\circ}$ ano e com $100 \%$ de adubação de reposição anual de Pe K; T2 - cultivo com calagem e adubação corretiva parcelada em cinco anos em superfície e com $75 \%$ da adubação de reposição anual de P e K em superficie; T3 - cultivo com calagem $e$ adubação corretiva parcelada em três anos em superfície e com $50 \%$ da reposição anual de $P$ e Kem superfície; T4 - cultivo com calagem e adubação corretiva em dois anos em superfície e com $25 \%$ da reposição anual de P e K em superfície; e T5 - solo sem cultivo, sem correção e adubação. Na rotação, cultivaram-se aveia-preta (Avena strigosa), soja (Glycine max), ervilhaca comum (Vicia sativa), milho (Zea mays), nabo forrageiro (Raphanus sativus) $e$ feijão-preto (Phaseolus vulgaris). A aplicação parcelada de corretivos e adubo mineral na superfície do solo em condição de semeadura direta, ao longo de três e cinco anos, resultou em melhor condição para o controle das perdas de solo do que parcelada em dois anos. O aumento da quantidade de adubo aplicado na superfície do solo sob semeadura direta elevou a produção de fitomassa e diminuiu as perdas de solo por erosão hídrica sob condição de cultivo. As perdas de água nos tratamentos com cultivo do solo sob semeadura direta foram baixas em todos os ciclos culturais, seguindo o mesmo comportamento das perdas de solo.
\end{abstract}

Termos de indexação: fitomassa cultural, perda de água, perda de solo, chuva natural.

\section{INTRODUCTION}

Soil erosion by water is complex and occurs in varying intensity, depending on the relative importance of climate, soil, relief, soil cover and additional conservation practices. Among these, soil cover and management are the most important individual factors (Wischmeier \& Smith, 1978). Lime and fertilizers, in their various quantities and application forms, are part of the soil management and therefore play an important role in the erosion of the soil by water because of the influence they have on plant biomass production. In the no-tillage system, the type and amount of biomass produced by the crops (Bezerra et al, 2006; Costa et al, 2008) influences the surface characteristics such as cover (Bertol et al., 1997) and roughness (Corrêa et al., 2012), and the sub-surface characteristics, such as density and porosity (Andrade et al., 2010), among other aspects. Thus, larger amounts of fertilizers applied to the soil provide greater production of crop mass and, thus, lower water erosion (Seixas, 2012).

Systems of soil conservation management are characterized by little or no mechanical disturbance, high surface cover resulting by the crop mass and, with the exception of no-tillage, high roughness. Moreover, in most cases, fertilizers and correctives are applied to the surface or lightly incorporated into the soil. These positive aspects diminish water erosion in the no-tillage system compared to the conditions in which the soil was plowed and harrowed by a tractor, without liming or fertilization, and is left fallow (Bertol et al., 1997; Leite et al., 2004; Bertol et al., 2008). The no-tillage system increases the critical shear stress of the soil and, consequently, its resistance to water erosion (Foster, 1982), and, as a result, soil losses are generally very low while water losses are not, compared to intensive tillage, in cultivated as well as in fallow areas (Schick, 2014).

No-tillage can be installed and conducted in several ways on farms: along or transverse to the slope, using different amounts of lime and fertilizers semi-incorporated into the soil or surface-applied, maintained for varying periods of time with various crops, on agricultural terracing or not, in addition to other variations in soil and crop management. This diversity of situations results in different degrees of resistance to water erosion in this management system, as reported in the literature (Panachuki et al., 2011; Barbosa et al., 2012; Mirás Avalos et al., 2012).

Studying the effect of different rates of inorganic fertilizer applied to citronella grass (Cymbopogon nardu), Seixas (2012) found a positive response to higher fertilizer rates in plant height, number of leaves and biomass production of the aerial part of the crop. Bezerra et al. (2006) evaluated the effect of different rates of organic and inorganic fertilizer on 
the dry weight of the aerial part of chambá (Justicia pectoralis), and noted a positive response. A similar study was conducted by Costa et al. (2008), evaluating the response to inorganic and organic fertilizer on lemongrass biomass production, showed that the production of dry biomass of the aerial part of the crop responded better to poultry manure than to other fertilizer types. In a study with soybean, Santos et al. (2009) observed a positive response in the biomass production of aerial parts and roots of the plants to applications of liquid swine manure.

Bertol et al. (2007) found higher water erosion in soil fertilized with liquid swine manure than with mineral fertilizer under simulated rainfall. In another work, Bagatini et al. (2011) found that the application of organic and inorganic fertilizer increased biomass production of aerial parts and roots of sorghum and thus reduced soil loss compared to the absence of fertilizers, with no influence on water losses. Gilles et al. (2009), working under simulated rainfall, found improved soil properties with the application of inorganic and organic fertilizer, due to the increase in biomass of maize roots and aerial parts, which reduced water and soil losses by water erosion.

This study aimed to quantify water erosion under natural rainfall for 10 years in a soil without cultivation and under no-tillage with various forms of implantation and conduction in terms of rate and mode of application of lime and inorganic fertilizer.

\section{MATERIAL AND METHODS}

Evaluations were carried out between March 2003 and April 2013, over 20 crop cycles in Lages, Santa Catarina, on plots $\left(27^{\circ} 49^{\prime}\right.$ south latitude and $50^{\circ} 20^{\prime}$ west longitude, at an average altitude of $937 \mathrm{~m}$ a.s.l.) with a Cfb climate, according to Köppen (Alvares et al., 2013), and an average annual rainfall of 1,533 $\mathrm{mm}$ (Schick et al., 2014a). The soil at the experimental site is a Leptic Aluminium Humic Dystrupept clay soil, classified according to the criteria described by Embrapa (2013), with the following characteristics in the 0-0.2 m layer: $110 ; 70 ; 420$; and $400 \mathrm{~g} \mathrm{~kg}^{-1}$ of fine sand, coarse sand, silt and clay, respectively; $40 \mathrm{~g} \mathrm{~kg}^{-1}$ of total organic carbon; and $2.54 \mathrm{~kg} \mathrm{dm}^{-3}$ particle density, according to Guadagnin (2003). At the beginning of the study, the soil had a density of $0.91 ; 1.29 ; 1.29$; and $1.26 \mathrm{~kg} \mathrm{dm}^{-3}$ in the $0-5 ; 5-10 ; 10-15$; and $15-20 \mathrm{~cm}$ layers, without variation between the sites where the treatments would be installed and, in the same layers, the macropore volume was, respectively, 0.15; 0.07; 0.07 ; and $0.07 \mathrm{~m}^{3} \mathrm{~m}^{-3}$, while the micropore volume was, respectively, $0.47 ; 0.42$; 0.42 ; and $0.42 \mathrm{~m}^{3} \mathrm{~m}^{-3}$.

Prior to evaluations, the soil was used as native pasture, and had been partially corrected 20 years before with surface applications of $4 \mathrm{Mg} \mathrm{ha}^{-1}$ of lime. In addition, at that time, exotic species of grasses and legumes were introduced, also in coverage, and the soil surface was slightly chiseled. Under this condition, the terrain was uniformized, by plowing in November 2002, three diskings with a spring tooth harrow in February 2003, and another plowing. In March 2003 the soil was disked twice, once to break the soil clods and a second time for soil leveling, followed by chiseling, plowing and leveling disking in early May 2003.

On May 10, 2003, the treatments were installed with variations in soil cultivation, liming and corrective fertilization (CQFSRS/SC, 2004) with P and $\mathrm{P}$ and $\mathrm{K}$ replenishment, in terms of rates and application forms (Table 1), which consisted of: T1 cultivated soil with lime and $\mathrm{P}$ fertilizer incorporated into the soil in the first year and with $100 \%$ annual replacement of $\mathrm{P}$ and $\mathrm{K}$, incorporated in the first year and on the surface in the following years; T2 cultivated soil with lime and corrective phosphorus fertilizer distributed over five years, with a fifth of the rate per year, applied to the surface, and with $75 \%$ of the annual fertilizer replacement of $\mathrm{P}$ and $\mathrm{K}$ applied on the surface; T3 - cultivated soil with lime and corrective phosphate fertilization distributed over three years, with one third of the rate per year, applied to the surface and $50 \%$ of the annual fertilizer replacement of $\mathrm{P}$ and $\mathrm{K}$ applied to the surface; T4 cultivated soil with lime and corrective phosphate fertilizer distributed over two years, with half the rate per year, applied to the surface and $25 \%$ of the annual fertilizer replacement of $\mathrm{P}$ and $\mathrm{K}$ applied to the surface; and T5 - bare soil, without correction or fertilization.

Lime and corrective fertilizer in $\mathrm{T} 1$ were distributed at two times of the same day, being incorporated into the soil, half before plowing and the other half before disking (T1). Lime was used to correct acidity, triple superphosphate as $\mathrm{P}$ source and potassium chloride as $\mathrm{K}$ source. The cultivations in T1, T2, T3 and T4 began with oats (Avena strigosa) using broadcast sowing $\left(120 \mathrm{~kg} \mathrm{ha}^{-1}\right)$, whose seeds were incorporated by light disking. This crop and the following were managed under no-tillage, with the rotation sequence: oats followed by soybean (Glycine max), common vetch (Vicia sativa), maize (Zea mays), forage radish (Raphanus sativus), and black beans (Phaseolus vulgaris). The crops in spring-summer (soybeans, corn and black beans) received replacement fertilization of $\mathrm{P}$ and $\mathrm{K}$, while in autumn-winter (oats, vetch and forage radish), were cultivated without this replacement, but with topdressing fertilization with urea as N source. Soybean, corn and beans were sown manually with a "saraquá" or "seed rattle" in lines parallel to the slope, spaced $0.45 ; 0.7$; and 0.45 $\mathrm{m}$ apart, respectively, and the pits spaced $0.2 \mathrm{~m}$ apart in the rows of the three crops. Oat, vetch and forage radish seeds were broadcast by hand on the soil surface. 
Table 1. Description of treatment $(T)$ regarding the cultivation, liming, corrective fertilization and replacement fertilization, in the treatments with soil cultivation (WSC) and without cultivation and uncovered (WCU), between 2003 and 2013

\begin{tabular}{|c|c|c|c|c|}
\hline \multicolumn{2}{|c|}{ T Cultivation } & \multirow{2}{*}{$\begin{array}{c}\text { Correction } \\
\text { with lime and } \mathbf{P}\end{array}$} & \multirow{2}{*}{$\begin{array}{c}\text { Splitting of the correction } \\
\text { with lime and } \mathbf{P} \\
\text { Single rate, incorporated in the } 1^{\text {st }} \text { year }\end{array}$} & \multirow{2}{*}{$\begin{array}{l}\begin{array}{c}\text { Dosage and method of application of } \\
\text { fertilizer replacement with PK }\end{array} \\
100 \% \text { of the rate, incorporated in } 1^{\text {st }} \text { year } \\
\text { and on the surface in the other years }\end{array}$} \\
\hline $\mathrm{T} 1$ & WSC & & & \\
\hline $\mathrm{T} 2$ & WSC & Whole & $\begin{array}{l}\text { Split in five applications: } 1 / 5 \text { rate per } \\
\text { year on surface }\end{array}$ & $75 \%$ of the rate applied on surface annually \\
\hline $\mathrm{T} 3$ & WSC & Whole & $\begin{array}{l}\text { Split in three applications: } 1 / 3 \text { rate } \\
\text { per year, on surface }\end{array}$ & $50 \%$ of the rate applied on surface annually \\
\hline $\mathrm{T} 4$ & WSC & Whole & $\begin{array}{l}\text { Split in two applications: } 1 / 2 \text { rate per } \\
\text { year on surface }\end{array}$ & $25 \%$ of the rate applied on surface annually \\
\hline T5 & WCU & Without application & Without application & Without application \\
\hline
\end{tabular}

The experimental units $(22.1 \times 3.5 \mathrm{~m})$ were delimited by galvanized sheets driven $0.1 \mathrm{~m}$ deep into the soil. At the lower end of the plots there was a runoff collector system, with a gutter to channel the eroded material, connected by a PVC pipe to a first sediment tank located $6 \mathrm{~m}$ below the plot. This in turn, was connected to a second storage tank, by a Geib-type flow divisor with nine openings.

The crop mass was determined in samples collected in $0.36 \mathrm{~m}^{2}$ at two points per plot by weighing after oven-drying at $50^{\circ} \mathrm{C}$. The soil cover by the remaining crop mass was determined after the sowing of each crop by the method of the marked rope, or a modification of the "meterstick" method proposed by Hartwig \& Laflen (1978).

Runoff samples for soil and water loss quantification were collected and processed by the method proposed by Cogo (1978). The soil losses observed in the field were adjusted to a standard slope of $0.09 \mathrm{~m} \mathrm{~m}^{-1}$, using the equation proposed by Wischmeier \& Smith (1978):

$$
\mathrm{S}=0.065+4.56 \operatorname{sen} \theta+65.41(\operatorname{sen} \theta)^{2},
$$

where $\mathrm{S}=$ slope factor of USLE; and $\theta=$ angle of slope of the land.

To calculate erosivity $\left(\mathrm{EI}_{30}\right)$, we used erosive rains. After the rains were determined in segments of uniform intensity, their kinetic energy was calculated with a specific computer spreadsheet, by a procedure recommended by Wischmeier \& Smith (1958) using the following equation:

$$
\mathrm{E}=0.119+0.0873 \log _{10} \mathrm{I},
$$

where $\mathrm{E}=$ kinetic energy per $\mathrm{mm}$ of rain, $\mathrm{MJ} \mathrm{mm} \mathrm{ha}^{-1} \mathrm{~h}^{-1}$; and $\mathrm{I}=$ rainfall intensity, $\mathrm{mm} \mathrm{h}^{-1}$.

With the same computer spreadsheet, the $\mathrm{EI}_{30}$ of the rain was calculated by multiplying $\mathrm{E}$ by the rain intensity in $30 \mathrm{~min}\left(\mathrm{I}_{30}\right)$, as proposed by Wischmeier $\&$ Smith (1978).
The soil loss ratio was calculated by dividing the soil loss from each crop treatment (T1, T2, T3 and T4) by the soil loss in the fallow treatment (T5), for each crop cycle. For each cycle, the rate of water loss was also calculated by dividing the depth of the runoff lost per treatment by the rainfall depth.

The data of crop dry mass, residue soil cover, soil loss and water loss were subjected to analysis of variance in a completely randomized design in a factorial arrangement. For analysis, the years/ cycles of each plant species were considered as replications. Thus, the treatments consisted in combinations of methods of soil correction and fertilization with different cultivated plant species. When necessary, Duncan's test was applied to compare the means of the two mentioned factors. For purposes of standardization and stabilization of variances, the individual values of soil loss were logarithmized, as indicated by the method of BoxCox transformation. However, the averages were presented in the original scale after application of the inverse transformation. Analyses were performed using SAS ${ }^{\circ}$ software (SAS, 2003) at a minimum significance level of $5 \%$. For the data of rainfall depth, $\mathrm{EI}_{30}$, ratio of soil and water loss, only the mean and standard deviation for cultivation were calculated. Simple regression was applied between values of soil and water loss; soil loss and erosivity; water loss and rainfall depth; and between the values of rainfall depth and erosivity. In all cases, the linear model $\mathrm{y}=\mathrm{a}+\mathrm{b} \mathrm{x}$ was adjusted. Regression consisted of adjusting the potential model $\mathrm{y}=\mathrm{a} \mathrm{x}^{\mathrm{b}}$ to the values of dry phytomass and the total amount of $\mathrm{P}$ and $\mathrm{K}$ applied to the soil, and the exponential model $y=a e^{-b x}$ to the data of total soil losses and dry phytomass. Graphics and regressions were prepared using the graphic software SigmaPlot®. 


\section{RESULTS AND DISCUSSION}

There was no interaction between treatments and crop cycles for the data of phytomass, soil cover, soil loss and water loss and therefore, only the comparisons for each variable are shown (Tables 2 and 3).

The dry mass of the aerial parts of the crops (DP) increased $35 \%$ from treatment $\mathrm{T} 4$ to $\mathrm{T} 1$ during the experimental period (Table 2), due to the larger amount of replacement fertilizer applied to the soil in $\mathrm{T} 4$. The variation between treatments in the periods of corrective fertilization from the beginning of the experiment contributed to this. This in turn, influenced the soil cover and water erosion, by affecting the soil physical characteristics, especially the quality of the structure. The influence of fertilization on DP production was also studied by Santos et al. (2009), in whose work, without splitting of fertilization, the authors observed an increased amount of dry mass of soybean residue with increasing fertilization applied to the soil.

The amount of DP varied widely between the crops studied (2 to $15 \mathrm{Mg} \mathrm{ha}^{-1}$ ), while corn and oats produced higher quantities than forage radish, black beans, vetch, and soybeans (Table 2), as similarly reported by Monegat (1991) and Calegari et al. (1993). These data demonstrate that corn and oats are essential in cultivation systems involving crop rotation, to increase the crop mass and stabilize the soil cover. With this, the no-tillage system that depends fundamentally on

Table 2. Dry crop mass and surface cover in each crop and crop cycle, in the treatments (T) with soil cultivation on a Humic Dystrupept soil, between March 2003 and April 2013

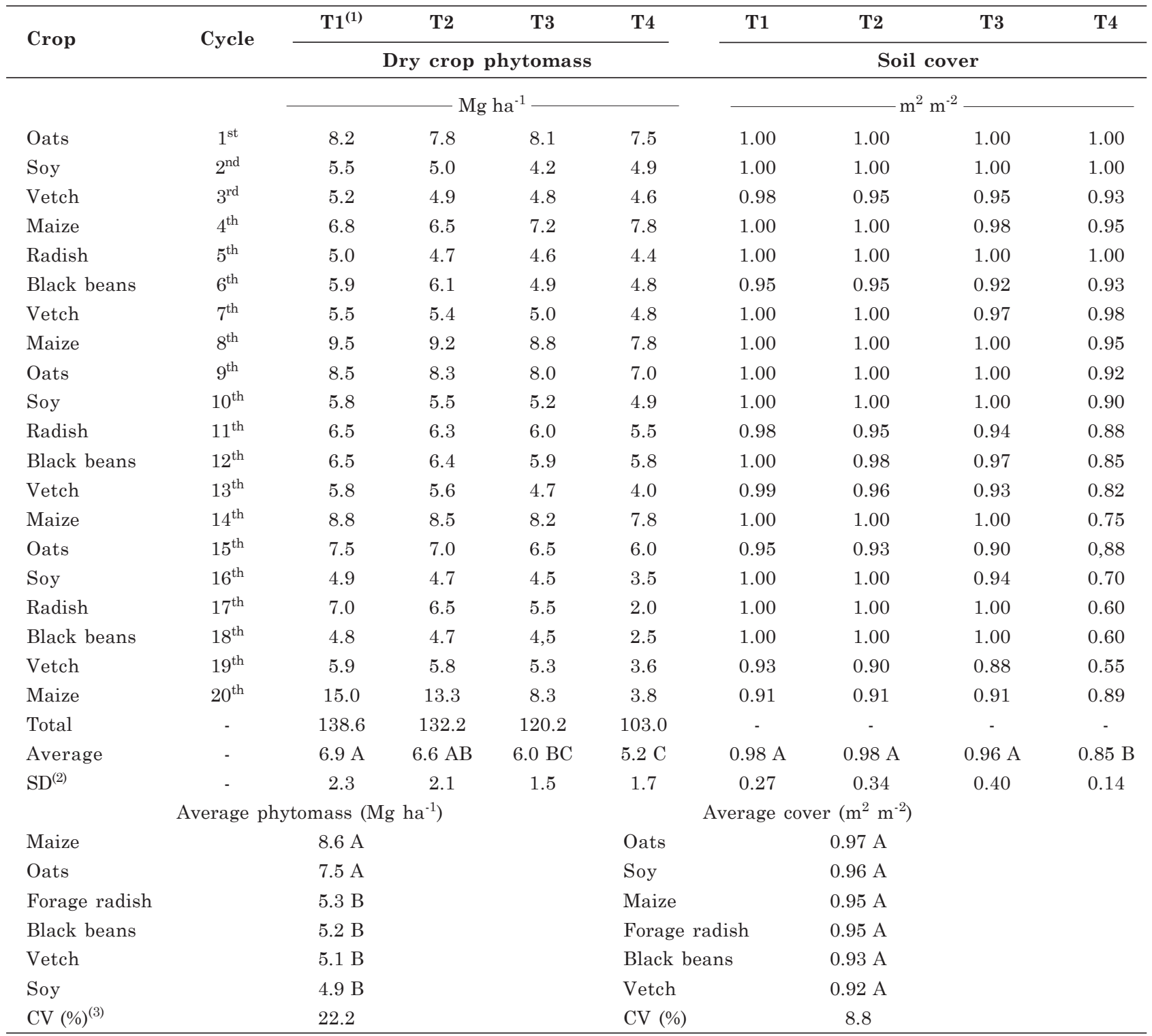

(1) T1; T2; T3; T4; T5: as described in Materials and Methods. ${ }^{(2)}$ SD: standard deviation. ${ }^{(3)} \mathrm{CV}$ : coefficient of variation. 
Table 3. Soil and water loss in each cultivation and crop cycle, in the treatments (T) with and without soil cultivation on a Humic Dystrupept soil between March, 2003 and April, 2013

\begin{tabular}{|c|c|c|c|c|c|c|c|c|c|c|c|}
\hline \multirow{2}{*}{ Crop } & \multirow{2}{*}{ Cycle } & $\mathrm{T} 1^{(1)}$ & T2 & T3 & $\mathbf{T} 4$ & T5 & T1 & $\mathbf{T} 2$ & T3 & $\mathbf{T} 4$ & T5 \\
\hline & & \multicolumn{3}{|c|}{ Soil loss } & & & \multicolumn{5}{|c|}{ Water loss } \\
\hline & \multirow[b]{2}{*}{$1^{\text {st }}$} & \multicolumn{4}{|c|}{$-\mathrm{kg} \mathrm{ha}^{-1}$} & \multirow[b]{2}{*}{170} & \multicolumn{4}{|c|}{$-\%$ of the rain } & \multirow[b]{2}{*}{0.3} \\
\hline Oats & & 104 & 35 & 28 & 77 & & 0.2 & 0.1 & 0.2 & 0.2 & \\
\hline Soy & $2^{\text {nd }}$ & 157 & 74 & 65 & 85 & 24,450 & 0.5 & 0.2 & 0.4 & 0.4 & 7.3 \\
\hline Vetch & $3^{\text {rd }}$ & 325 & 129 & 163 & 650 & 47,916 & 2.5 & 2.7 & 6.2 & 5.5 & 14.0 \\
\hline Maize & $4^{\text {th }}$ & 90 & 36 & 48 & 51 & 22,510 & 0.2 & 0.2 & 0.2 & 0.2 & 8.2 \\
\hline Radish & $5^{\text {th }}$ & 232 & 70 & 195 & 404 & 72,319 & 1.4 & 2.0 & 4.7 & 6.5 & 16.1 \\
\hline Black beans & $6^{\text {th }}$ & 17 & 9 & 14 & 59 & 36,055 & 0.6 & 0.4 & 0.4 & 0.4 & 19.9 \\
\hline Vetch & $7^{\text {th }}$ & 105 & 55 & 91 & 128 & 10,663 & 0.8 & 1.3 & 3.6 & 2.5 & 9.6 \\
\hline Maize & $8^{\text {th }}$ & 163 & 40 & 66 & 116 & 27,996 & 1.6 & 0.8 & 1.4 & 1.3 & 18.7 \\
\hline Oats & $9^{\text {th }}$ & 122 & 337 & 238 & 555 & 28,809 & 1.5 & 1.2 & 2.3 & 1.8 & 20.0 \\
\hline Soy & $10^{\text {th }}$ & 790 & 550 & 387 & 293 & 61,431 & 0.7 & 0.5 & 0.6 & 0.5 & 15.5 \\
\hline Radish & $11^{\text {th }}$ & 126 & 152 & 122 & 591 & 28,238 & 4.6 & 4.3 & 10.0 & 10.5 & 19.2 \\
\hline Black beans & $12^{\text {th }}$ & 22 & 10 & 7 & 8 & 37,155 & 1.1 & 0.7 & 1.0 & 1.0 & 24.0 \\
\hline Vetch & $13^{\text {th }}$ & 602 & 395 & 217 & 297 & 40,233 & 3.7 & 2.9 & 7.6 & 9.6 & 19.8 \\
\hline Maize & $14^{\text {th }}$ & 80 & 13 & 31 & 1,706 & 49,476 & 1.3 & 1.1 & 2.8 & 3.0 & 28.2 \\
\hline Oats & $15^{\text {th }}$ & 291 & 106 & 348 & 541 & 22,546 & 5.8 & 6.8 & 11.1 & 9.9 & 23.5 \\
\hline Soy & $16^{\text {th }}$ & 26 & 36 & 73 & 112 & 77,826 & 4.4 & 4.9 & 9.0 & 8.2 & 28.1 \\
\hline Radish & $17^{\text {th }}$ & 226 & 97 & 506 & 1,237 & 50,114 & 12.5 & 9.6 & 14.3 & 21.4 & 28.1 \\
\hline Black beans & $18^{\text {th }}$ & 36 & 30 & 33 & 82 & 15,189 & 1.6 & 1.8 & 4.1 & 4.2 & 9.6 \\
\hline Vetch & $19^{\text {th }}$ & 9 & 9 & 36 & 31 & 19,916 & 3.4 & 2.6 & 5.2 & 5.2 & 7.7 \\
\hline Maize & $20^{\text {th }}$ & 24 & 15 & 15 & 48 & 62,747 & 0.7 & 1.3 & 1.1 & 1.4 & 16.6 \\
\hline Total & - & 3,547 & 2,198 & 2,683 & 7,071 & 735,759 & 2.5 & 2.3 & 4.3 & 4.7 & 16.7 \\
\hline Average & - & $177 \mathrm{BC}$ & $110 \mathrm{C}$ & $134 \mathrm{C}$ & $354 \mathrm{~B}$ & $36.78 \mathrm{~A}$ & $2.5 \mathrm{~B}$ & $2.3 \mathrm{~B}$ & $4.3 \mathrm{~B}$ & $4.7 \mathrm{~B}$ & $16.7 \mathrm{~A}$ \\
\hline $\mathrm{SD}^{(2)}$ & - & 201 & 147 & 141 & 443 & 20838 & 2.9 & 2.5 & 4.2 & 5.3 & 7.8 \\
\hline \multicolumn{6}{|c|}{ Average soil loss $\left(\mathrm{kg} \mathrm{ha}^{-1}\right)$} & \multicolumn{5}{|c|}{ Average water loss (\% of the rain) } & \\
\hline \multicolumn{3}{|c|}{ Forage Radish } & \multicolumn{3}{|c|}{$1,424 \mathrm{~A}$} & \multicolumn{3}{|c|}{ Forage Radish } & \multicolumn{2}{|c|}{$11.0 \mathrm{~A}$} & \\
\hline \multicolumn{3}{|l|}{ Soy } & \multicolumn{3}{|c|}{$868 \mathrm{AB}$} & \multicolumn{3}{|c|}{ Soy } & \multicolumn{2}{|c|}{$5.8 \mathrm{~B}$} & \\
\hline \multicolumn{3}{|l|}{ Vetch } & \multicolumn{3}{|c|}{$768 \mathrm{AB}$} & \multicolumn{3}{|l|}{ Vetch } & \multicolumn{2}{|r|}{$5.7 \mathrm{~B}$} & \\
\hline \multicolumn{3}{|l|}{ Oats } & \multicolumn{3}{|c|}{$550 \mathrm{AB}$} & Oats & & & & $5.4 \mathrm{~B}$ & \\
\hline Maize & & & & $533 \mathrm{ABC}$ & & Maize & & & & $4.7 \mathrm{~B}$ & \\
\hline Black beans & & & & $346 \mathrm{C}$ & & Black be & & & & $4.5 \mathrm{~B}$ & \\
\hline CV $(\%)^{(3)}$ & & & & 21.5 & & $\mathrm{CV}(\%)$ & & & & 4.5 & \\
\hline
\end{tabular}

(1) T1; T2; T3; T4; T5: as described in Materials and Methods. ${ }^{(2)}$ SD: standard deviation. ${ }^{(3)} \mathrm{CV}$ : coefficient of variation.

a high DP production and soil cover to be considered a soil conservation system, becomes viable.

The soil cover by mass of aerial plant parts (SC) varied less than the DP between the treatments (Table 2), It decreased by $13 \%$ from $\mathrm{T} 1$ to $\mathrm{T} 4$ in the mean of the evaluation period, and varied from 0.55 to $0.1 \mathrm{~m}^{2} \mathrm{~m}^{-2}$ between the crops. The smaller numeric variation in SC than in DP can be explained by the fact that the former depends more on the management form and distribution of crop residues on the soil surface, while the latter depends more on the amount and type of phytomass, as shown by Lopes et al. (1987), which justifies the statistical equality of SC between crops. The SC is the main factor of dissipation of the kinetic energy of raindrops (Wischmeier \& Smith, 1978) and of reduction of water erosion in soil management systems. It should therefore be increased, especially in the case of notillage systems, where soil roughness is low and the surface layer is generally thickened.

Soil losses (SL) were low in the treatments T1, T2, T3 and T4 in all crops, with few exceptions (Table 3 ), compared to the soil loss tolerance estimated by Bertol \& Almeida (2000) for this soil, agreeing with data obtained by other authors in studies of this nature, in no-tillage systems (Bertol et al., 1997; Leite et al., 2004; Amaral et al., 2008). The SL values showed a wide variation between 7 and $1706 \mathrm{~kg} \mathrm{ha}^{-1}$ in treatments with soil cultivation, determined by the effect of treatment, crop type and rainfall erosivity (Table 4). In T5, where the soil was left fallow throughout the whole evaluation period, the values of 
SL were high from the second crop onwards compared to the values estimated by Bertol \& Almeida (2000), i.e., ranging from 10,663 to $77,826 \mathrm{~kg} \mathrm{ha}^{-1}$ in this period (Table 3 ). High values of losses from bare soil were also reported by Schick et al. (2000), Amaral et al. (2008) and Schick et al. (2014b), in experiments with the same soil type. The high soil losses in T5 are explained by the absence of a crop and soil cover, which intensified the erosion process by the impact of the raindrops and runoff, causing the detachment and transport of soil particles.

The forms of application of lime and corrective fertilizers and the amount of fertilizer replacement applied to the soil caused high variation of SL between treatments $\mathrm{T} 1$ and $\mathrm{T} 4$ in the average of the experimental period (Table 3), reflecting, in part, the effect of the variation in DP and SC. Thus, these two treatments affected soil losses by water erosion, due to their effect on the crop mass production, as well as on the soil cover, as also reported by Bezerra et al. (2006), Costa et al. (2008) and Seixas (2012). The treatments T1, T2 and T3 were more effective in controlling SL than T4, in the average of the trial period. Thus, the application of lime and corrective fertilizers incorporated into the soil (T1) or on the surface (T2 and T3) and distributed over five (T2) and three (T3) years, resulted in a better control of soil

Table 4. Rainfall depth and erosivity for each crop and crop cycle, on a Humic Dystrupept soil, between March 2003 and April 2013

\begin{tabular}{lccc}
\hline Crop & Cycle & Rainfall depth & Erosivity $\mathbf{( E I}_{\mathbf{3 0}}$ ) \\
\hline & & $\mathrm{mm}$ & MJ mm ha $^{-1} \mathrm{~h}^{-1}$ \\
Oats & $1^{\text {st }}$ & 389 & 872 \\
Soy & $2^{\text {nd }}$ & 720 & 2,386 \\
Vetch & $3^{\text {rd }}$ & 845 & 2,538 \\
Maize & $4^{\text {th }}$ & 534 & 1,549 \\
Forage radish & $5^{\text {th }}$ & 1,234 & 3,724 \\
Black beans & $6^{\text {th }}$ & 462 & 1,787 \\
Vetch & $7^{\text {th }}$ & 464 & 654 \\
Maize & $8^{\text {th }}$ & 768 & 2,716 \\
Oats & $9^{\text {th }}$ & 825 & 1,603 \\
Soy & $10^{\text {th }}$ & 691 & 3,041 \\
Forage radish & $11^{\text {th }}$ & 812 & 1,556 \\
Black beans & $12^{\text {th }}$ & 415 & 1,486 \\
Vetch & $13^{\text {th }}$ & 1,049 & 2,815 \\
Maize & $14^{\text {th }}$ & 819 & 3,146 \\
Oats & $15^{\text {th }}$ & 944 & 2,469 \\
Soy & $16^{\text {th }}$ & 833 & 5,190 \\
Forage radish & $17^{\text {th }}$ & 762 & 2,075 \\
Black beans & $18^{\text {th }}$ & 376 & 1,539 \\
Vetch & $19^{\text {th }}$ & 446 & 1,204 \\
Corn & $20^{\text {th }}$ & 589 & 2,058 \\
Average & - & 699 & 2,220 \\
SD & - & 236 & 1,030 \\
\hline SD standart & & &
\end{tabular}

SD: standart deviation. losses than surface application and distribution over two years. This effect did not occur in regards to the control of water loss, comparing these treatments, mainly because there was no difference regarding SC.

In bare soil (T5), soil losses (Table 2) were 29.3\% higher during the spring/summer, determined by rainfall erosivity (Table 3) which, in this period of the year, were $27.6 \%$ higher than in autumn/winter, in the mean of the crop cycles. The water losses (WL), on the other hand, were $1.8 \%$ higher in spring/summer, while the rainfall depth was $20 \%$ lower. Thus, the difference in PS was due to rainfall erosivity while in PA, this difference was probably due to the average rainfall intensity, which is usually lowest in the fall/ winter in this region, as stated by Schick et al. (2014a).

Water losses (WL) were low in treatments T1, T2, $\mathrm{T} 3$ and T4 in all crop cycles (Table 3), with some exceptions, following the same trend of SL (Table 3), in agreement with data obtained by other authors in works of this nature under no-tillage system (Schick et al., 2000; Amaral et al., 2008). Water losses varied less than SL in the treatments with cultivation, in between 0.1 and $21.4 \%$ of the rains; this variation was determined by the effect of crop type and rainfall depthfall (Table 4). In T5, the PA values were highest from the $2^{\text {nd }}$ crop on, ranging, in this period, between 7.3 and $28.2 \%$ of the rains. High water losses from bare soil were also observed by Schick et al. (2000), Amaral et al. (2008) and Schick et al. (2014b). Smaller variations in water than in soil losses were stated in most studies of this nature, e.g., Lopes et al. (1987), Carvalho et al. (1990), Amaral et al. (2008) and Barbosa et al. (2012), in accordance with the principles presented by Kohnke (1968).

The depth and erosivity $\left(\mathrm{EI}_{30}\right)$ of the rains had normal variation in the evaluation period, with averages of $699 \mathrm{~mm}$ for rain and 2,220 MJ mm ha-1 $\mathrm{h}^{-1}$ for erosivity, per crop cycle, with a standard deviation of 236 and 1030, respectively (Table 4). The $\mathrm{EI}_{30}$ is influenced primarily by the rainfall intensity in the various segments and its maximum intensity in 30 min and, secondarily, by the total rainfall depth (Wischmeier \& Smith, 1978), which justifies its temporal variation. Considering two crop cycles per growing season, doubling the average values per cultivation of rainfall depth $(699 \mathrm{~mm})$ and of $\mathrm{EI}_{30}$ $\left(2,220 \mathrm{MJ} \mathrm{mm} \mathrm{ha}{ }^{-1} \mathrm{~h}^{-1}\right)$, annual values of $1,398 \mathrm{~mm}$ of rain and of $4,440 \mathrm{MJ} \mathrm{mm} \mathrm{ha-1} \mathrm{h}^{-1}$ for erosivity are estimated for the experimental site. These values are, respectively, 9 and $12 \%$ lower than those obtained by Schick et al. (2014a) for the period between 1989 and 2012 at the same location.

The ratio of soil (RSL) and water loss (RWL) is a good indicator of the efficacy of a particular management system, in terms of the ability to reduce water erosion in relation to a condition of continuously fallow and bare soil (Wischmeier \& Smith, 1978). The data in table 5 indicate high efficacy of the treatments with soil cultivation to control water erosion. Among 
Table 5. Rate of soil and water loss in each crop and crop cycle in the treatments (T) with and without soil cultivation, on a Humic Dystrupept soil, between March 2003 and April 2013

\begin{tabular}{|c|c|c|c|c|c|c|c|c|c|c|c|}
\hline \multirow{2}{*}{ Crop } & \multirow{2}{*}{ Cycle } & $\mathrm{T} 1^{(1)}$ & T2 & T3 & $\mathbf{T} 4$ & T5 & T1 & $\mathbf{T} 2$ & T3 & $\mathbf{T} 4$ & T5 \\
\hline & & \multicolumn{5}{|c|}{ Rate of soil loss } & \multicolumn{5}{|c|}{ Rate of water loss } \\
\hline Oats & $1^{\text {st }}$ & 0.612 & 0.206 & 0.165 & 0.453 & 1 & 0.002 & 0.001 & 0.002 & 0.002 & 0.003 \\
\hline Soybean & $2^{\text {nd }}$ & 0.006 & 0.003 & 0.003 & 0.003 & 1 & 0.005 & 0.002 & 0.004 & 0.004 & 0.073 \\
\hline Vetch & $3^{\text {rd }}$ & 0.007 & 0.003 & 0.003 & 0.014 & 1 & 0.025 & 0.027 & 0.062 & 0.055 & 0.140 \\
\hline Maize & $4^{\text {th }}$ & 0.004 & 0.002 & 0.002 & 0.002 & 1 & 0.002 & 0.002 & 0.002 & 0.002 & 0.082 \\
\hline Radish & $5^{\text {th }}$ & 0.003 & 0.001 & 0.003 & 0.006 & 1 & 0.014 & 0.020 & 0.047 & 0.065 & 0.161 \\
\hline Black bean & $6^{\text {th }}$ & 0.000 & 0.000 & 0.000 & 0.002 & 1 & 0.006 & 0.004 & 0.004 & 0.004 & $0.19 s$ \\
\hline Vetch & $7^{\text {th }}$ & 0.010 & 0.005 & 0.009 & 0.012 & 1 & 0.008 & 0.013 & 0.036 & 0.025 & 0.096 \\
\hline Maize & $8^{\text {th }}$ & 0.006 & 0.001 & 0.002 & 0.004 & 1 & 0.016 & 0.008 & 0.014 & 0.013 & 0.187 \\
\hline Oats & $9^{\text {th }}$ & 0.004 & 0.012 & 0.008 & 0.019 & 1 & 0.015 & 0.012 & 0.023 & 0.018 & 0.200 \\
\hline Soybean & $10^{\text {th }}$ & 0.013 & 0.009 & 0.006 & 0.005 & 1 & 0.007 & 0.005 & 0.006 & 0.005 & 0.15 \\
\hline Radish & $11^{\text {th }}$ & 0.004 & 0.005 & 0.004 & 0.021 & 1 & 0.046 & 0.043 & 0.100 & 0.105 & 0.192 \\
\hline Black beans & $12^{\text {th }}$ & 0.000 & 0.000 & 0.000 & 0.000 & 1 & 0.011 & 0.007 & 0.010 & 0.010 & 0.240 \\
\hline Vetch & $13^{\text {th }}$ & 0.015 & 0.010 & 0.005 & 0.007 & 1 & 0.037 & 0.029 & 0.076 & 0,096 & 0.198 \\
\hline Maize & $14^{\text {th }}$ & 0.002 & 0.000 & 0.000 & 0.034 & 1 & 0.013 & 0.011 & 0.028 & 0.030 & 0.282 \\
\hline Oats & $15^{\text {th }}$ & 0.012 & 0.005 & 0.015 & 0.024 & 1 & 0.058 & 0.068 & 0.111 & 0.099 & 0.235 \\
\hline Soybeans & $16^{\text {th }}$ & 0.000 & 0.000 & 0.001 & 0.014 & 1 & 0.044 & 0.049 & 0.090 & 0.082 & 0.281 \\
\hline Radish & $17^{\text {th }}$ & 0.005 & 0.002 & 0.010 & 0.025 & 1 & 0.125 & 0.096 & 0.143 & 0.214 & 0.281 \\
\hline Black bean & $18^{\text {th }}$ & 0.002 & 0.002 & 0.002 & 0.005 & 1 & 0.016 & 0.018 & 0.041 & 0.042 & 0.096 \\
\hline Vetch & $19^{\text {th }}$ & 0.000 & 0.000 & 0.002 & 0.002 & 1 & 0.034 & 0.026 & 0.052 & 0.052 & 0.077 \\
\hline Maize & $20^{\text {th }}$ & 0.000 & 0.000 & 0.000 & 0.001 & 1 & 0.007 & 0.013 & 0.011 & 0.014 & 0.166 \\
\hline Average & - & 0.035 & 0.013 & 0.012 & 0.033 & 1 & 0.025 & 0.023 & 0.043 & 0.047 & 0.167 \\
\hline $\mathrm{SD}^{(2)}$ & - & 0.136 & 0.045 & 0.036 & 0.099 & 0 & 0.029 & 0.025 & 0.042 & 0.053 & $0.07 \varepsilon$ \\
\hline
\end{tabular}

(1) T1; T2; T3; T4; T5: as described in Materials and Methods. ${ }^{(2)}$ SD: standard deviation.

them the treatments T2 and T3 were particularly efficient in controlling soil loss and $\mathrm{T} 1$ and $\mathrm{T} 2$ in controlling water loss, being the most efficient on the average of the experimental period. Therefore, the application of lime and corrective fertilizers distributed over five (T2) and three (T3) years since the establishment of the experiment in soil surface applications, was more advantageous than the other ways of applying the correctives, in regards to the creation of conditions for the control of soil losses in no-tillage systems. The greater efficacy of $\mathrm{T} 1$ compared to the other treatments for the control of water loss is explained by the greater amount of phytomass produced in that treatment (Table 2).

The soil losses by erosion were explained by the water loss (Figure 1a) agreeing with Bertol et al. (2013) and by the erosivity $\left(\mathrm{EI}_{30}\right)$ of rainfall (Figure $1 \mathrm{~b}$ ) in the condition of uncovered and untilled soil, according to Wischmeier \& Smith (1978), by simple linear regression for the bare soil. The difference of significance between the two relations indicates that the erosivity $\left(\mathrm{EI}_{30}\right)$ of the rain effectively has greater influence on soil losses $\left(\mathrm{R}^{2}=0.66^{* *}\right)$ than runoff alone $\left(\mathrm{R}^{2}=0.36^{*}\right)$, as reported in Wischmeier \& Smith (1978), in the case of bare soil. The inclination value of the straight line in figure $1 \mathrm{~b}(0.0160)$ indicates an approximation of the erodibility index of the soil (K factor of Universal Soil Loss Equation - USLE), whose value approach the value determined by Schick et al. (2014b) for the same soil, with data for the period between 2002 and 2012.

Water losses were related weakly with rainfall depth on bare soil without cultivation (Figure 1c). This indicates that other variables of soil surface explain the largest of the water losses, which demonstrates the complexity involved in the study of erosion, given the number of factors influencing this phenomenon, according to Wischmeier \& Smith (1978). The values of rainfall depth explained the erosivity $\left(\mathrm{EI}_{30}\right)$, at a 5 $\%$ significance level (Figure 1d). The value of $\mathrm{EI}_{30}$ calculated at 5,190 MJ mm ha-1 $\mathrm{h}^{-1}$ due a rainfall of $833 \mathrm{~mm}$ (Table 4), measured in one of the soybean crops, was the only point in figure 1 responsible for the lowering of the significance from 1 to $5 \%$ in this relation. This type of dispersion that occurs when relating data of $\mathrm{EI}_{30}$ index and rainfall depth is normal, as already noted by other authors (Santos \& Montenegro, 2012; Oliveira et al., 2012; Schick et al., 2014a) because of the large temporal variability in the characteristics of the rain, which, sometimes, do not correspond to the variability in the $\mathrm{EI}_{30}$.

The phytomass production was explained by the amount of fertilizer added to the soil at $1 \%$ significance level (Figure 2a). This positive correlation is explained 

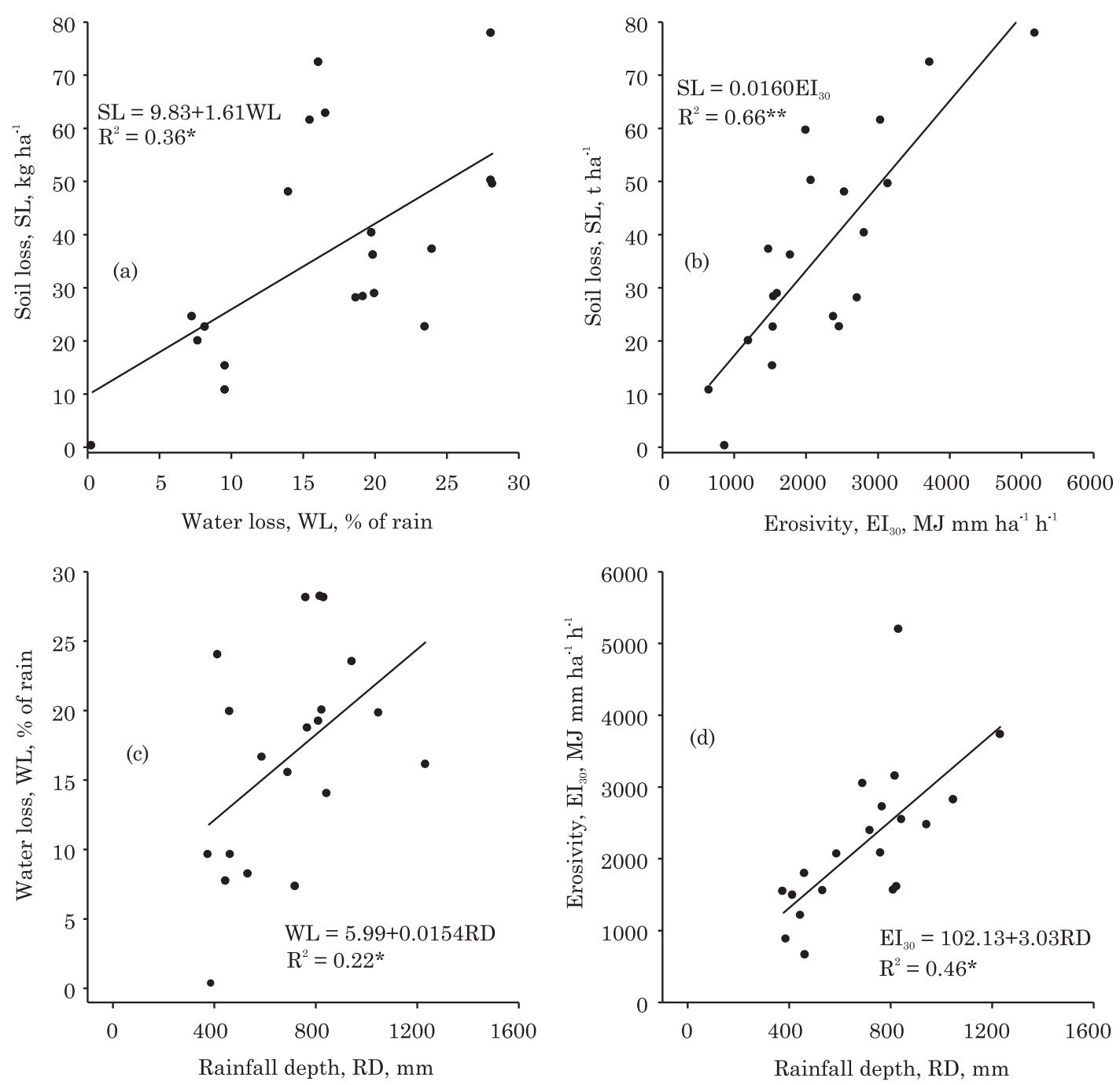

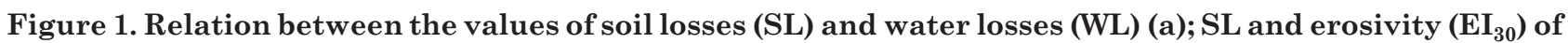
rainfall (b); WL and rainfall depth (RD), involving data from bare and uncovered soil (T5) (c); and $\mathrm{EI}_{30}$ and RD (d), on a Humic Dystrupept soil, between March 2003 and April 2013. **: significant at $1 \%$ $(p<0.01)$ and $*$ significant at $5 \%(0.01 \leq p<0.05)$.
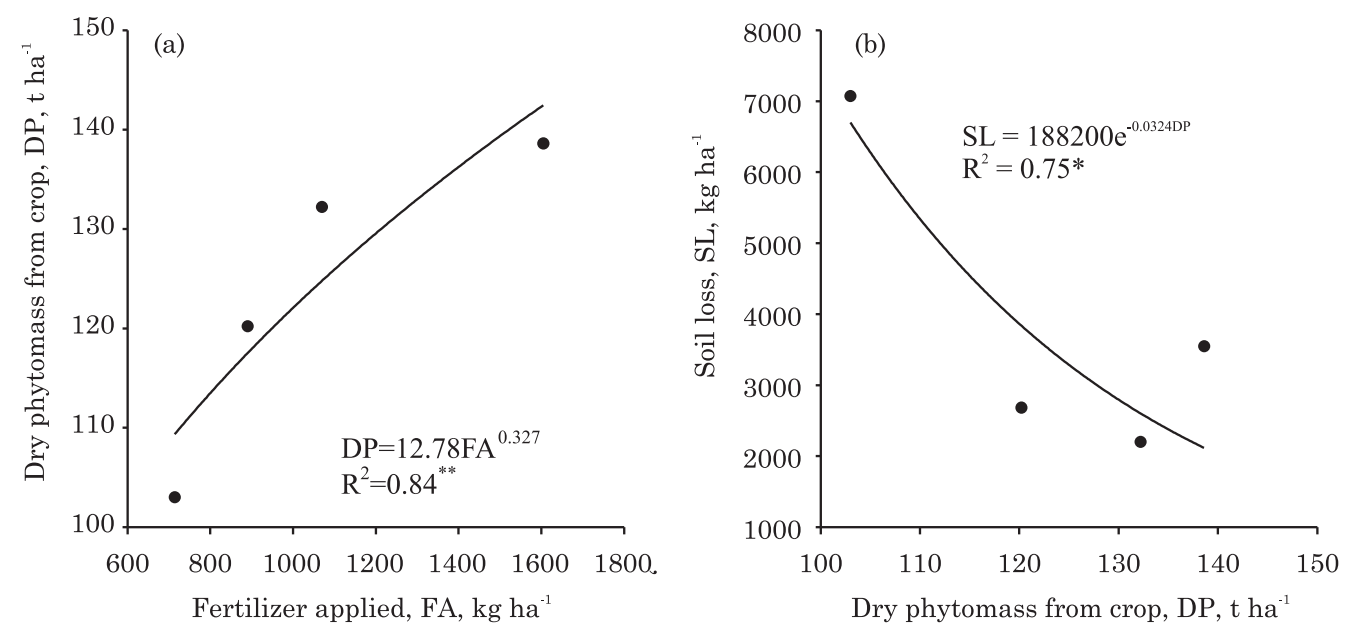

Figure 2. Relation between the dry phytomass from the crop (DP) and the total amount of fertilizer applied to the soil (FA) (a) and between total soil loss (SL) and the total DP (b), on a Humic Dystrupept soil between March 2003 and April 2013. 
by the demand for nutrients for plant growth. This type of soil is characterized by high leaching of bases and high levels of exchangeable $\mathrm{Al}$ (Almeida et al., 1997), resulting in a condition of low fertility. Thus, fertilizer application significantly increases the phytomass production. The soil loss had an exponentially decreasing relation with the phytomass at the $5 \%$ significance level (Figure $2 \mathrm{~b}$ ), indicating that the higher the phytomass production, left on the surface, the smaller the soil losses, according to Wischmeier \& Smith (1978). These relations demonstrate the importance of the application and management of fertilizers to reduce the phenomenon of water erosion of the soil due to the positive influence on crop growth and development.

\section{CONCLUSIONS}

1. The split application of lime and mineral fertilizer on the soil surface in no-tillage systems, over three and five years, results in better condition for the control of soil losses than split in two years.

2. Increasing the amount of fertilizer applied to the soil surface under no-tillage increases phytomass production and reduces soil loss by water erosion in cultivated systems.

3. Water losses in treatments with soil cultivation under no-tillage are low in all crop cycles, following the same behavior of soil losses.

\section{AKNOWLEDGEMENTS}

We would like to thank CNPq and FAPESC, for the financial resources to conduct the experiment. We are also indebted to the following Scientific Initiation scholarship grantees, for their help with the field and laboratory work: Wilson Antonio Zoldan Junior, André Júlio do Amaral, Leonardo Felipe Brignoni, Diego Cecchin Brambatti, Sidinei Roberto Ritter, Rodrigo Daltoé Bercí, Rafael Pegoraro, Eduardo Zavaschi, Evandro Luiz Fabian, Bruno Mezzomo Barroso, Julio César Ramos, Marcelo Masahiko Takizawa, Romeu de Souza Werner, Thalita Dal Toé Benincá, Douglas Henrique Bandeira, Marco Segalla Prazeres, Mitsui Shinosaka Tanaka, Hugo Castelani dos Santos, Eduardo Zandonadi Gambá, and Vinicius Silveira Marques.

\section{LITERATURE CITED}

AMARAL, A.J.; BERTOL, I.; COGO, N.P. \& BARBOSA, F.T. Redução da erosão hídrica em três sistemas de manejo do solo em um Cambissolo Húmico da região do Planalto Sul-Catarinense. R. Bras. Ci. Solo, 32:2145-2155, 2008.
ALMEIDA, J.A.; KÄMPF, N. \& ALMEIDA, R. Caracterização mineralógica de Cambissolos originados de rochas pelíticas nos patamares do alto rio Itajaí e no Planalto de Lages (SC). R. Bras. Ci. Solo, 21:180-190, 1997.

ALVARES, C.A.; STAPE, J.L.; SENTELHAS, P.C.; GONÇALVES, J.L.M \& SPAROVEK, G. Köppen's climate classification map for Brazil. Meteorol. Z., 22:711728, 2013.

ANDRADE, A.P.; MAFRA, A.L.; BALDO, G.R.; DELA PÍCCOLLA, C.; BERTOL, I. \& ALBUQUERQUE, J.A. Physical properties of a Humic Cambisol under tillage and cropping systems after 12 years. R. Bras. Ci. Solo, 34:219-226, 2010 .

BAGATINI, T.; COGO, N.P.; GILLES, L.; PORTELA, J.C.; PORTZ, G. \& QUEIROZ, H.T. Perdas de solo e água por erosão hídrica após mudança no tipo de uso da terra, em dois métodos de preparo do solo e dois tipos de adubação. R. Bras. Ci. Solo, 35:999-1011, 2011.

BARBOSA, F.T.; BERTOL, I.; WERNER, R.S.; RAMOS, J.C. \& RAMOS, R.R. Comprimento crítico de declive relacionado à erosão hídrica, em três tipos e doses de resíduos em duas direções de semeadura direta. R. Bras. Ci. Solo, 36:1279-1290, 2012.

BERTOL, I. \& ALMEIDA, J.A. Tolerância de perda de solo por erosão para os principais solos do estado de Santa Catarina. R. Bras. Ci. Solo, 24:657-668, 2000.

BERTOL, I.; COGO, N.P. \& LEVIEN, R. Erosão hídrica em diferentes preparos do solo logo após as colheitas de milho e trigo, na presença e ausência dos resíduos culturais. R. Bras. Ci. Solo, 21:409-418, 1997.

BERTOL, O.; RIZZI, N.E.; BERTOL, I. \& ROLOFF, G. Perdas de solo e água e qualidade do escoamento superficial associadas à erosão entre sulcos em área cultivada sob semeadura direta e submetida às adubações mineral e orgânica. R. Bras. Ci. Solo, 31:781-792, 2007.

BERTOL, I.; RAMOS, R.R.; BARBOSA, F.T.; PAZ GONZÁLEZ, A.; RAMOS, J.C. \& BANDEIRA, D.H. Water erosion in no-tillage monoculture and intercropped systems along contour lines. R. Bras. Ci. Solo, 37:521-528, 2013.

BERTOL, I.; ZOLDAN JUNIOR, W.A.; FABIAN, E.L.; ZAVASCHI, E.; PEGORARO, R. \& PAZ GONZÁLEZ, A. Efeito de escarificação e da erosividade de chuvas sobre algumas variáveis de valores de erosão hídrica em sistemas de manejo de um Nitossolo Háplico. R. Bras. Ci. Solo, 32:747-757, 2008.

BEZERRA, A.M.E.; NASCIMENTO JUNIOR, F.T.; LEAL, F.R. \& MELO CARNEIRO, J.G. Rendimento de biomassa, óleo essencial, teores de fósforo e potássio de chambá em resposta à adubação orgânica e mineral. R. Ci. Agron., 37:124-129, 2006.

CALEGARI, A.; MONDARDO, A.; BULISANI, E.A.; WILDNER, L.P.; COSTA, M.B.B.; ALCÂNTARA, P.B.; MIYASAKA, S. \& AMADO, T.J.C.A. Adubação verde no Sul do Brasil. 2.ed. Rio de Janeiro, AS-PTA, 1993. 346p. 
CARVALHO, F.L.C.; COGO, N.P. \& LEVIEN, R. Eficácia relativa de doses e formas de manejo do resíduo cultural de trigo na redução da erosão hídrica do solo. R. Bras. Ci. Solo, 13:251-257, 1990.

COMISSÃO DE QUÍMICA E FERTILIDADE DO SOLO CQFSRS/SC. Manual de adubação e calagem para os Estados do Rio Grande do Sul e Santa Catarina. 10.ed. Porto Alegre, SBCS/Núcleo Regional Sul/UFRGS, 2004. 400p.

COGO, N.P. Uma contribuição à metodologia de estudo das perdas de erosão em condições de chuva natural. I. Sugestões gerais, medição dos volumes, amostragem e quantificação de solo e água da enxurrada (1 ${ }^{\mathrm{a}}$ aproximação). In: ENCONTRO NACIONAL DE PESQUISA SOBRE CONSERVAÇÃO DO SOLO, 2., Passo Fundo, 1978. Anais... Passo Fundo, Embrapa-CNPT, 1978. p.75-98.

CORRÊA, I.M.C.; BERTOL, I.; RAMOS, J.C. \& TAKIZAWA, M.M. Rugosidade da superfície de um Cambissolo Húmico relacionada com o preparo e compactação do solo sob chuva natural. R. Bras. Ci. Solo, 36:567-576, 2012.

COSTA, L.C.B.; ROSAL, L.F.; PINTO, J.E.B.P. \& BERTOLICCI, S.K.V. Efeito da adubação química e orgânica na produção de biomassa e óleo essencial em capim-limão (Cymbopogon citratus (DC.) Stapf.)). R. Bras. Plantas Med., 10:16-20, 2008.

EMPRESA BRASILEIRA DE PESQUISA AGROPECUÁRIA EMBRAPA. Centro Nacional de Pesquisa de Solos. Sistema brasileiro de classificação de solos. 3.ed. Rio de Janeiro, 2013. 353p.

FOSTER, G.R. Modeling the erosion process. In: BASSELMAN, J.A., ed. Hydrological modeling of small watersheds. Madison, American Society of Agricultural Engineers, 1982. p.297-300.

GILLES, L; COGO, N.P.; BISSANI, C.A.; BAGATINI, T. \& PORTELA, J.C. Perdas de água, solo, matéria orgânica e nutriente por erosão hídrica na cultura do milho implantada em área do campo nativo, influenciadas por métodos de preparo do solo e tipos de adubação. R. Bras. Ci. Solo, 33:1427-1440, 2009.

GUADAGNIN, J. Perdas de nutrientes e carbono orgânico pela erosão hídrica, em um Cambissolo Húmico alumínico léptico submetido a diferentes sistemas de preparo e cultivo do solo. Lages, Universidade do Estado de Santa Catarina, 2003. 103p. (Dissertação de Mestrado)

HARTWIG, R.O. \& LAFLEN, I.M. A meter stick method for measuring crop residue cover. J. Soil Water Conserv., 33:90-91, 1978.

KOHNKE, H. Soil physics. New York, McGraw-Hill, 1968. 224p.

LEITE, D.; BERTOL, I.; GUADAGNIN, J.C.; SANTOS, E.J. \& RITTER, S.R. Erosão hídrica em um Nitossolo Háplico submetido a diferentes sistemas de manejo sob chuva simulada: I. Perdas de solo e água. R. Bras. Ci. Solo, 28:1033-1044, 2004.

LOPES, P.R.C.; COGO, N.P. \& LEVIEN, R. Eficácia relativa de tipo e quantidade de resíduos culturais espalhados uniformemente sobre o solo na redução da erosão hídrica. R. Bras. Ci. Solo, 11:71-75, 1987.
MIRÁS AVALOS, J.M.; SANDE FOUZ, P.; BERTOL, I. \& PAZ GONZÁLEZ, A. Crop residue effects on calcium, magnesium, potassium, and sodium runoff losses from a soil prone to crusting. Commun. Soil Sci. Plant Anal., 43:315-323, 2012.

MONEGAT, C. Plantas de cobertura do solo, características e manejo em pequenas propriedades. Chapecó, Edição do Autor, 1991. 337p.

OLIVEIRA, P.T.S.; WENDLAND, E. \& NEARING, M.A. Rainfall erosivity in Brazil: A review. Catena, 100:139147, 2012.

PANACHUKI, E.; BERTOL, I.; ALVES SOBRINHO, T.; OLIVIERA, P.T.S. \& BICCA, D.B. Perdas de solo e de água e infiltração de água em Latossolo Vermelho sob sistemas de manejo. R. Bras. Ci. Solo, 35:1777-1785, 2011.

SANTOS, C.J.L.; MENEZES, J.F.S.; GONÇALVES JUNIOR, D.; GONÇALVES, M.E.M.P. \& SILVA, T.R. Produção de massa seca da parte aérea e de raízes da soja adubada com dejeto líquido de suínos. In: SIMPÓSIO INTERNACIONAL SOBRE GERENCIAMENTO DE RESÍDUOS DE ANIMAIS. USO DOS RESÍDUOS DA PRODUÇÃO ANIMAL COMO FERTILIZANTE, 1., Florianópolis, 2009. Anais... Florianópolis, 2009. CD-ROM

SANTOS, T.E.M. \& MONTENEGRO, A.A.A. Erosividade e padrões hidrológicos de precipitação no Agreste Central pernambucano. R. Bras. Eng. Agric. Amb., 16:871-880, 2012.

SAS Institute Inc ${ }^{\circledR}$. Statistical Analysis System, ver. 9.1.3. Cary, 2003.

SEIXAS, P.T.L. Efeito da adubação mineral na produção de biomassa, teor e composição do óleo essencial e fungitoxicidade in vitro do capim-citronela. Gurupi, Universidade Federal do Tocantins, 2012. 89p. (Dissertação de Mestrado)

SCHICK, J. Fatores R e K da USLE e perdas de solo e água em sistemas de manejo sobre um Cambissolo Húmico em Lages, SC. Lages, Universidade do Estado de Santa Catarina, 2014. 149p. (Tese de Doutorado)

SCHICK, J.; BERTOL, I.; BATISTELA, O. \& BALBINOR JÚNIOR, A.A. Erosão hídrica em Cambissolo Húmico alumínico submetido a diferentes sistemas de preparo e cultivo do solo: I. Perdas de solo e água. R. Bras. Ci. Solo, 24:427-436, 2000.

SCHICK, J.; BERTOL, I.; COGO, N.P.; PAZ GONZÁLEZ, A. \& BARBOSA, F.T. Erosividade das chuvas de Lages (SC). R. Bras. Ci. Solo, 2014a. p.1890-1905.

SCHICK, J.; BERTOL, I.; COGO, N.P.; PAZ GONZÁLEZ, A. \& BARBOSA, F.T. Erodibilidade de um Cambissolo Húmico em Lages (SC). R. Bras. Ci. Solo, 2014b. p.1906-1917.

WISCHMEIER, W.H. \& SMITH, D.D. Predicting rainfall erosion losses: A guide to conservation planning. Washington, USDA, 1978. 58p. (Agricultural Handbook, 537)

WISCHMEIER, W.H. \& SMITH, D.D. Rainfall energy and its relationship to soil loss. Trans. Am. Geophys. Union, 39:285-291, 1958. 